ZOOLOGIA 28 (3): 285-290, June, 2011

doi: $10.1590 /$ S1984-46702011000300001

\title{
Efficacy of clove oil as anesthetic in handling and transportation of Nile tilapia, Oreochromis niloticus (Actinopterygii: Cichlidae) juveniles
}

\author{
Larissa N. Simões ${ }^{1}$; Danielle C. Lombardi ${ }^{1}$; Andrea T. M. Gomide ${ }^{1}$ \& Levy C. Gomes ${ }^{1,2}$ \\ ${ }^{1}$ Centro Universitário Vila Velha. Rua Comissário José Dantas de Melo 21, Boa Vista, 29102-770 Vila Velha, ES, Brazil. \\ 2 Corresponding Author. E-mail: levy.gomes@uvv.br
}

\begin{abstract}
This work evaluated the efficiency of clove oil as anaesthetic in handling and transportation of Nile tilapia, Oreochromis niloticus (Linnaeus, 1758). In the first experiment, safety concentrations of clove oil were assessed by measuring induction times to anaesthesia. The second experiment evaluated exposure times to anaesthetic. Clove oil efficiency during transportation was evaluated in a $24 \mathrm{~h}$ experiment using three concentrations of the anaesthetic $(0,9$, and $\left.18 \mathrm{mg} \cdot \mathrm{L}^{-1}\right)$. The most appropriate clove oil concentration to induce surgical anaesthesia was $90 \mathrm{mg} \cdot \mathrm{L}^{-1}$. To biometry or other brief handling, the recommended concentration is $50-60 \mathrm{mg} \cdot \mathrm{L}^{-1}$ as it provides fast recovery. Maximum anaesthesia time should be $10 \mathrm{~min}$. The mortality rate of fish transported using $18 \mathrm{mg} \cdot \mathrm{L}^{-1}$ of anaesthetic was significantly higher than that of the control group at $24 \mathrm{~h}$ of transportation and at $96 \mathrm{~h}$ after transportation. The fish transported using clove oil as anaesthetic presented more significant $\mathrm{Na}^{+}$and $\mathrm{K}^{+}$disorders as compared to the control group. As an anaesthetic, clove oil is efficient in the handling of Nile tilapia in routine fish hatchery procedures, although it should be avoided in the transportation.
\end{abstract}

KEY WORDS. Eugenol; net ion flux; stress; tropical fish.

In Brazil, tilapia farming is usually carried out in two distinct sites: the hatchery station, where reproduction and sex reversion are conducted and juveniles grow up to $5 \mathrm{~cm}$, and growing station, where the $5 \mathrm{~cm}$ fish reach harvest size. Anaesthesia is required in several procedures conducted in hatchery and growth stations (Ross \& Ross 2008).

In tilapia hatcheries, the handling and transportation of large numbers of fish are the procedures in which anaesthesia is especially required. In general, the handling of fish is an extreme procedure, but of short duration, which leads to acute stress (KIEssLING et al. 2009). In turn, transportation is an essential step in the production process and likewise is considered to increase stress in fish. In spite of the advancements in farming techniques, fish mortality caused by poor management and transportation strategies still lead to losses in the tilapia hatcheries.

In Brazil, the most widely utilized chemical anaesthetics are obtained with difficulty, and for many producers costs are prohibitive (Roubach et al. 2005). In this scenario, the use of essential oils extracted from plants has proved to be a feasible alternative to chemical anaesthetics during fish handling and transportation (KAISER et al. 2006, PÁlIC et al. 2006, SIMÕES \& GOMES 2009). The main substance used is clove oil, extracted from the leaves and buds of the tree Eugenia caryophyllata (Linnaeus). The active principle is eugenol which concentration in clove oil is between 70 and $90 \%$. Clove oil is considered an appropriate anaesthetic for fish because of its low costs, simple obtaining, and considerable anaesthetic efficiency. Also, the substance ap- parently does not exert any toxic effect (Ross \& Ross 2008). Clove oil has been extensively used in several fish species, and the results show that the substance is a good economic alternative to the chemicals normally used in fish anaesthesia (reviewed by Ross \& Ross 2008). The Nile tilapia, Oreochromis niloticus (Linnaeus, 1758), is the fish most commonly grown in Brazil, and one of the most cultured in the world (FAO 2007). Nevertheless, there was no literature on the use of anaesthetics with juveniles of this species in hatcheries. The present study was designed to test the efficiency of clove oil as an anaesthetic in handling and transportation procedures of Nile tilapia juveniles.

\section{MATERIAL AND METHODS}

\section{Clove oil as anaesthetic during handling}

Ninety Nile tilapia juveniles $(1.46 \pm 0.38 \mathrm{~g}, 4.33 \pm 0.30$ $\mathrm{cm}$ ) were obtained from a commercial supplier and transported to our research laboratory, where the individuals were acclimated in two $150 \mathrm{~L}$ tanks equipped with continuous water inflow and aeration. Acclimation lasted 10 days, throughout which period water quality parameters were monitored every three days, with values as follows: dissolved oxygen $\left(5.99 \pm 1.23 \mathrm{mg} . \mathrm{L}^{-1}\right)$; temperature $\left(26.7 \pm 0.96{ }^{\circ} \mathrm{C}\right)$; conductivity $\left(66.49 \pm 3.09 \mu \mathrm{S} . \mathrm{cm}^{-1}\right)$; hardness $\left(23.62 \pm 3.29 \mathrm{mgCaCO}_{3} \cdot \mathrm{L}^{-1}\right)$; water flow $(1.43 .20 \pm$ 0.41.13 L.min $\left.{ }^{-1}\right)$ and $\mathrm{pH}(6.70 \pm 0.15)$. During acclimation fish were fed daily with specific commercial fish feed containing $36 \%$ of crude protein. 
After acclimation, the tests were carried out in $6 \mathrm{~L}$ static aquaria containing $2 \mathrm{~L}$ water. Recovery was always conducted in $45 \mathrm{~L}$ plastic aquaria filled with $20 \mathrm{~L}$ water and constant aeration. Water quality parameters during tests were as follows: dissolved oxygen $\left(8.15 \pm 0.44 \mathrm{mg} . \mathrm{L}^{-1}\right)$; temperature $(27.5 \pm 0.34$ $\left.{ }^{\circ} \mathrm{C}\right)$; conductivity $\left(67.73 \pm 1.00 \mu \mathrm{S} . \mathrm{cm}^{-1}\right)$; hardness $(25.02 \pm 1.42$ $\left.\mathrm{mgCaCO}_{3} \cdot \mathrm{L}^{-1}\right)$; and $\mathrm{pH}(6.52 \pm 0.10)$. Prior to use, a $1: 10(\mathrm{v} / \mathrm{v})$ stock solution of clove oil (Petite Marie; SP, Brazil; density 1,03 $\mathrm{g} \mathrm{cm}^{-3}, 90 \%$ de eugenol) was prepared with ethanol 95\%. The water in each aquarium was replaced at the end of each test.

In the first experimental segment, six different clove oil concentrations were tested $\left(50,60,70,80,90\right.$, and 100 mg.L $\left.\mathrm{L}^{-1}\right)$. For each concentration, 10 fish were individually exposed to the anaesthetic for $10 \mathrm{~min}$. The aim was to observe the induction time in seconds for each anaesthesia stage. After exposure, each fish was transferred to the recovery aquarium. The different induction stages were assessed according to the criteria proposed by Sтоккорғ (1993). Recovery was defined as the full-range, active swimming of fish inside the recovery aquarium.

The second experimental segment evaluated the safety concentration of the anaesthetic based on the results of the first experiment. Recovery time was measured after the induction of anaesthesia at different exposure times with $90 \mathrm{mg} . \mathrm{L}^{-1}$ clove oil. The concentration of $90 \mathrm{mg} . \mathrm{L}^{-1}$ was chosen as the most appropriate because it caused the interruption of oppercular beat rates at the shortest time and the induction of all anaesthesia stages. The previously acclimated fish were individually exposed to the anaesthetic for 10, 20, and $30 \mathrm{~min}$ (n $=10$ for each exposure time). After exposure, each fish was transferred to the recovery aquarium and the recovery time measured.

Behavioral events and recovery time results are expressed as mean and standard deviation. The times to reach the different anaesthesia stages under the different clove oil concentrations, as well as the recovery times after exposure to the anaesthetic for different anaesthesia times were evaluated using an analysis of variance (ANOVA) followed by the Tukey test ( $\mathrm{p}<0.05)\left(Z_{\mathrm{AR}} 1999\right)$.

\section{Clove oil as anaesthetic during transportation}

For this experiment, 2,700 Nile tilapia $(0.43 \pm 0.11 \mathrm{~g}$; $3.27 \pm 0.21 \mathrm{~cm}$ ) provided by the fish farm Bioalevinos (Ibiraçú, ES, Brazil) were used. The fish were captured in a breeding tank and transferred to a $500 \mathrm{~L}$ depuration tank equipped with constant water inflow and kept there for $24 \mathrm{~h}$. The water quality parameters measured were: dissolved oxygen $\left(6.85 \mathrm{mg} . \mathrm{L}^{-1}\right)$; temperature $\left(25.3^{\circ} \mathrm{C}\right)$; conductivity $\left(45.8 \mu \mathrm{S} . \mathrm{cm}^{-1}\right)$; hardness $(10.01$ $\left.\mathrm{mgCaCO} \cdot \mathrm{L}^{-1}\right)$; water inflow (4.94 L. $\left.\mathrm{min}^{-1}\right)$; $\mathrm{CO}_{2}\left(8.8 \mathrm{mg} \cdot \mathrm{L}^{-1}\right)$; ammonia (below the detection limit) and $\mathrm{pH} 7.58$.

Fish were transported in 27 6-L plastic bags containing $2 \mathrm{~L}$ water and pure oxygen, to a final volume that took up $90 \%$ of the bag's total capacity. Next, all bags were sealed with rubber stringers. Fish density was 50 fish/L (100 fish per bag). The trans- portation experiment was done in a factorial design with three clove oil concentration ( 0,9 and $18 \mathrm{mg} \cdot \mathrm{L}^{-1}$ clove oil) and three transportation times $(6,12$ and $24 \mathrm{~h})$. These concentrations are 10 and $20 \%$ of the ideal concentration for surgical anaesthesia, choose in the first experiment. Three replicates were conducted for each combination of time versus anaesthetic concentration. Transport trial started 8 o'clock in the morning and were done in paved road, with six hours of actual transportation until arrival in the laboratory, where it was held over 18 hours of simulated transport, totaling 24 hours of transport.

At the end of the transportation period, all bags were opened and mortality, water parameters and $\mathrm{Na}^{+}$and $\mathrm{K}^{+}$flux values measured. The fish from each bag were transferred to $30 \mathrm{~L}$ tanks with constant aeration and monitored for $96 \mathrm{~h}$ to evaluate accumulated mortality rate.

Dissolved oxygen, temperature and electric conductivity were measured using a YSI 85 multiparameter monitor (Yellow Spring Inc., Yellow Spring, USA). pH was monitored using a digital potentiometer (Quimis Q-400, Quimis, São Paulo, Brazil). Water hardness and $\mathrm{CO}_{2}$ were evaluated by titration, total ammonia was measured according to the endophenol technique, all measurements were conducted in accordance with the guidelines defined by APHA (1998).

The concentrations of $\mathrm{Na}^{+}$and of $\mathrm{K}^{+}$in water were measured directly using a flame photometer (Analyser 910, Analyser, São Paulo, Brazil). Net ion fluxes (Jnet) were calculated from the changes in the ion concentration of the water of transportation over the sampling periods according to the equation of Gonzalez et al . (1998): Jnet $=\mathrm{V}\left([\mathrm{ion}]_{1}-[\text { ion }]_{2}\right) .(\mathrm{Mt})^{-1}$, where $[\text { ion }]_{1}$ and $[i o n]_{2}$ are the bath ion concentrations at the beginning and end of the flux period, respectively, $\mathrm{V}$ is the bath volume in liters, $\mathrm{M}$ is the mass of the fish in $\mathrm{kg}$, and $\mathrm{t}$ is the duration of the flux period in hours. In transportation water, the mean initial $\mathrm{Na}^{+}$concentrations were $350,315.6$ and $317.8 \mu \mathrm{mol} . \mathrm{L}^{-1}$, while for $\mathrm{K}^{+}$these concentrations were $18,12.1$ and $12 \mu \mathrm{mol}^{-\mathrm{L}^{-1}}$ for fish transported in 0,9 , and $18 \mathrm{mg} . \mathrm{L}^{-1}$ clove oil, respectively.

Results are expressed as means \pm SD and data from mortality and accumulated mortality were $\log +1$ transformed before statistical analysis. The mortality, accumulated mortality, water quality and ion flux results were calculated based on a two-way ANOVA followed by the Tukey test $(\mathrm{p}<0.05)$ (ZAR 1999).

\section{RESULTS AND DISCUSSION}

\section{Clove oil as anaesthetic during handling}

Clove oil as used in the concentrations 80, 90, and 100 $\mathrm{mg} . \mathrm{L}^{-1}$ induced all anaesthesia stages in fish; however, the fish anaesthetized with $90 \mathrm{mg} . \mathrm{L}^{-1}$ reached total loss of equilibrium and had lower oppercular movement rates at a significantly shorter time, as compared to the those using the lower concentrations tested. At $100 \mathrm{mg} . \mathrm{L}^{-1}$, clove oil led to a $20 \%$ mortal- 
ity rate in the anaesthetized fish. Therefore, $90 \mathrm{mg} . \mathrm{L}^{-1}$ should be considered as the ideal clove oil concentration indicated for the induction of surgical anaesthesia (total loss of movement and minimum oppercular movement, no reaction to stimulus) in Nile tilapia juveniles (Tab. I).

The concentrations required for induction of anaesthesia vary with fish species and size, both for clove oil and for other anaesthetics, and are probably related to the particular species metabolism (Ross \& Ross 2008). Ideal clove oil concentrations lie within 10 and $50 \mathrm{mg} . \mathrm{L}^{-1}$ for a wide variety of fish species, such as the Atlantic salmon, Salmo salar Linnaeus, 1758 (Iversen et al. 2003); the largemouth bass, Micropterus salmoides (Lacepède, 1802) (Соoke et al. 2004); the gilthead seabream, Sparus aurata Linnaeus, 1758 (Mylonas et al. 2005); and the fathead minnow, Pimephales promelas Rafinesque, 1820 (PÁlıC et al. 2006). On the other hand, species like the eel, Anguilla reinhardtii Steindachner, 1867 (Walsh \& PeAse 2002) and tambaqui, Colossoma macropomum (Cuvier, 1816) (Roubach et al. 2005) require higher concentrations, which vary between 65 and $80 \mathrm{mg} . \mathrm{L}^{-1}$ for the induction of surgical anaesthesia.

In brief procedures, the adequate anaesthetic concentration should promote total loss of equilibrium without necessarily inducing all anaesthesia stages (see Tab. I to all anaesthetic stages details). In the present study, the concentrations of 50 , 60, 70 and $80 \mathrm{mg} . \mathrm{L}^{-1}$ clove oil promoted total loss of equilibrium at similar intervals, and promote the fast recovery of fish anaesthetized with the compound. Therefore, 50-60 mg. $\mathrm{L}^{-1}$ is the optimal concentration range to induce anaesthesia in handling of the Nile tilapia (Tab. I).

The recovery times after exposure to a $90 \mathrm{mg} . \mathrm{L}^{-1}$ solution of clove oil for 10 and $20 \mathrm{~min}$ were respectively $359.1 \pm 41.9 \mathrm{~s}$ and $560.8 \pm 123.35 \mathrm{~s}$, with no statistically significant difference. However, $50 \%$ of the fish that were anaesthetized for 20 min died, and the mortality rate of fish anaesthetized for 30 min reached 100\%. WATERSTRAT (1999) observed similar results with anaesthetized channel catfish juveniles, Ictalurus punctatus (Rafinesque, 1818) using $100 \mathrm{mg} . \mathrm{L}^{-1}$ clove oil, in an experiment that showed that exposure times of over 20 min increase recovery time and mortality rates. Ross \& Ross (2008) are cautious and believe $10 \mathrm{~min}$ to be the maximum anaesthesia time - a finding that was corroborated in the present study.

\section{Clove oil as anaesthetic during transportation}

As part of the handling procedures in intensive fish farming, transportation times may vary considerably, depending on the distance covered. As a rule, juveniles are transported from a hatchery to growth stations. In this process, the fish should arrive in good physiological conditions to meet the criteria demanded by the buyer (CARNeIro et al. 2002).

All the concentrations tested in the present study caused hyperactivity in fish, as of the first moment of exposure to the anaesthetic. This, was manifested as the swift movements of the animals inside the plastic bags, which decreased as the anaesthetic effect of clove oil increased. After the $6 \mathrm{~h}$ transportation period, the fish exposed to $9 \mathrm{mg} \cdot \mathrm{L}^{-1}$ clove oil presented reduced response to stimuli, which included slight sedation, differently from the fish anaesthetized with $18 \mathrm{mg} . \mathrm{L}^{-1}$, in which the majority of the individuals presented total loss of equilibrium. After 12 and $24 \mathrm{~h}$ of transportation, fish transported in clove oil at the two concentrations tested lost response to stimuli. According to CoOKe et al. (2004), the anaesthesia stages desired in transportation are manifested as the partial loss of response to stimuli and partial loss of equilibrium. The authors studied different clove oil concentrations with M. salmoides, and maintain that optimal anaesthetic concentrations for the transportation of this fish species are within the 5-8.5 mg. $\mathrm{L}^{-1}$ range.

Water temperature was similar across concentration treatments in the 6 and $12 \mathrm{~h}$ transportation periods. In the $24 \mathrm{~h}$ transportation period, water temperature was the same across the groups treated with different clove oil concentrations, but this temperature was significantly higher than the value measured at 6 and $12 \mathrm{~h}$ (Tab. II). Throughout this experiment, temperature variation was under $1^{\circ} \mathrm{C}$.

Table I. Induction times, to the different anaesthesia stages in O. niloticus juveniles exposed to different concentrations of clove oil. Behavioral events adapted from STOSKOPF (1993). Different letters in the columns indicate statistical difference between concentrations in one same anaesthesia stage by the ANOVA and Tukey test (5\%).

\begin{tabular}{|c|c|c|c|c|c|c|}
\hline \multirow{2}{*}{ Clove oil $\left(\mathrm{mg} \cdot \mathrm{L}^{-1}\right)$} & \multicolumn{6}{|c|}{ Behavioral events (seconds) } \\
\hline & $\begin{array}{l}\text { Loss of reaction } \\
\text { to stimulus }\end{array}$ & $\begin{array}{c}\text { Partial loss of } \\
\text { equilibrium }\end{array}$ & $\begin{array}{l}\text { Total loss of } \\
\text { equilibrium }\end{array}$ & $\begin{array}{c}\text { Reduction oppercular } \\
\text { movements }\end{array}$ & $\begin{array}{c}\text { Total loss of oppercular } \\
\text { movements }\end{array}$ & Recovery \\
\hline 50 & $24.7 \pm 1.0^{a}$ & $43.7 \pm 2.3^{a}$ & $90.9 \pm 7.0^{a}$ & $344.1 \pm 14.2^{a}$ & - & $177.4 \pm 21.2^{a}$ \\
\hline 60 & $20.2 \pm 1.0^{b}$ & $32.0 \pm 1.7^{b}$ & $90.0 \pm 9.8^{a}$ & $219.0 \pm 12.4^{b}$ & - & $163.0 \pm 15.9$ a \\
\hline 70 & $16.9 \pm 1.1 \mathrm{bc}$ & $28.8 \pm 1.4^{b c}$ & $83.6 \pm 4.8^{a b}$ & $348.7 \pm 6.7^{a}$ & - & $287.5 \pm 18.1^{a b}$ \\
\hline 80 & $17.5 \pm 0.5^{b}$ & $34.0 \pm 1.5^{b}$ & $95.6 \pm 5.3^{a}$ & $212.5 \pm 7.7^{b}$ & $545.0 \pm 25.0^{a}$ & $220.0 \pm 15.5^{a}$ \\
\hline 90 & $13.4 \pm 0.8^{\mathrm{cd}}$ & $23.5 \pm 2.1 \mathrm{~cd}$ & $86.6 \pm 10.8$ ab & $147.0 \pm 14.0^{c}$ & $281.0 \pm 15.1^{\mathrm{b}}$ & $379.0 \pm 71.8^{b}$ \\
\hline $100 \dagger$ & $9.6 \pm 0.7^{d}$ & $17.6 \pm 1.2^{d}$ & $56.6 \pm 3.7^{b}$ & $126.8 \pm 6.9^{c}$ & $199.2 \pm 6.5^{c}$ & $377.1 \pm 35.6^{b}$ \\
\hline
\end{tabular}

$\dagger$ Mortality rate of $20 \%$. 
Table II. Water quality after transportation of $O$. niloticus juveniles for different times and at different clove oil concentrations. Data were analyzed by Two-way ANOVA and Tukey test $(p<0.05)$. Lower case letters indicate statistical difference of the different treatments at one same transportation time. Upper case letters indicate statistical difference of different transportation times for one same treatment.

\begin{tabular}{|c|c|c|c|}
\hline \multirow{2}{*}{$\begin{array}{l}\text { Transportation time } \\
\text { (hour) }\end{array}$} & \multicolumn{3}{|c|}{ Clove oil concentration (mg. $\left.\mathrm{L}^{-1}\right)$} \\
\hline & 0 & 9 & 18 \\
\hline \multicolumn{4}{|l|}{ Temperature $\left({ }^{\circ} \mathrm{C}\right)$} \\
\hline 6 & $25.3 \pm 0.09$ aа & $25.3 \pm 0.06$ aа & $25.3 \pm 0.15$ aа \\
\hline 12 & $25.3 \pm 0.09$ аa & $25.2 \pm 0.13$ aа & $25.3 \pm 0.12$ аa \\
\hline 24 & $25.8 \pm 0.03 \mathrm{aB}$ & $25.8 \pm 0.06^{\mathrm{aB}}$ & $25.7 \pm 0.09 \mathrm{aB}$ \\
\hline \multicolumn{4}{|l|}{$\begin{array}{l}\text { Dissolved Oxygen } \\
\left(\mathrm{mg}^{\left.-L^{-1}\right)}\right.\end{array}$} \\
\hline 6 & $16.1 \pm 1.25$ аа & $13.2 \pm 0.73$ аа & $13.6 \pm 0.24$ аа \\
\hline 12 & $13.4 \pm 1.44$ аав & $9.2 \pm 0.56$ ba & $13.7 \pm 1.14$ aа \\
\hline 24 & $10.9 \pm 1.97 \mathrm{aB}$ & $5.0 \pm 0.48$ bB & $4.1 \pm 1.03$ bB \\
\hline \multicolumn{4}{|l|}{$\begin{array}{l}\text { Conductivity } \\
\left(\mu \mathrm{s} . \mathrm{cm}^{-1}\right)\end{array}$} \\
\hline 6 & $94.2 \pm 1.87$ аа & $98.9 \pm 0.74$ aа & $104.9 \pm 2.24$ аа \\
\hline 12 & $129.9 \pm 3.80$ abB & $126.7 \pm 2.49$ ав & $145.2 \pm 4.38 \mathrm{bB}$ \\
\hline 24 & $198.8 \pm 3.99 \mathrm{ac}$ & $178.9 \pm 0.28 \mathrm{bc}$ & $162.0 \pm 12.89$ \\
\hline \multicolumn{4}{|l|}{$\mathrm{pH}$} \\
\hline 6 & $6.4 \pm 0.10$ aа & $6.6 \pm 0.08$ ba & $6.7 \pm 0.04$ ba \\
\hline 12 & $6.1 \pm 0.02 \mathrm{aв}$ & $6.1 \pm 0.01$ ав & $6.2 \pm 0.03$ ав \\
\hline 24 & $6.0 \pm 0.02 \mathrm{aB}$ & $5.9 \pm 0.04 \mathrm{abB}$ & $5.7 \pm 0.11 \mathrm{bc}$ \\
\hline \multicolumn{4}{|l|}{$\mathrm{CO}_{2}\left(\mathrm{mg} \cdot \mathrm{L}^{-1}\right)$} \\
\hline 6 & $58.7 \pm 1.47$ аа & $51.3 \pm 5.29$ aba & $41.9 \pm 2.10$ ba \\
\hline 12 & $48.4 \pm 6.60$ aа & $50.6 \pm 0.00$ aa & $41.8 \pm 1.27$ аа \\
\hline 24 & $80.7 \pm 0.73 a \mathrm{aB}$ & $90.2 \pm 5.54$ abB & $98.3 \pm 1.94$ bв \\
\hline \multicolumn{4}{|l|}{$\begin{array}{l}\text { Total ammonia } \\
\left(\mathrm{mg} \cdot \mathrm{L}^{-1}\right)\end{array}$} \\
\hline 6 & $4.8 \pm 1.42$ aа & $4.7 \pm 0.84$ aa & $3.1 \pm 3.37$ aа \\
\hline 12 & $6.3 \pm 0.84$ aa & $4.7 \pm 0.65$ aa & $6.9 \pm 0.26 \mathrm{aaB}$ \\
\hline 24 & $10.1 \pm 3.37$ аа & $11.7 \pm 0.20 \mathrm{aB}$ & $9.3 \pm 1.23$ ав \\
\hline
\end{tabular}

Oxygen levels were higher in the $6 \mathrm{~h}$ transportation time followed by a continuous decrease in the parameter, up to $24 \mathrm{~h}$ transportation time in all groups. At the end of the transportation experiment, dissolved oxygen was significantly higher in the control group as compared to the groups transported using clove oil. A pronounced consumption of oxygen was seen in fish treated with the anaesthetic in the 12 and in the $24 \mathrm{~h}$ measurements. This may be linked with the hyperactivity in fish, at the first moment of exposure to the anaesthetic, especially in the $18 \mathrm{mg} . \mathrm{L}^{-1}$ clove oil concentration. Therefore, considering fish anaesthetized with clove oil at concentrations between 9 and $18 \mathrm{mg} \cdot \mathrm{L}^{-1}$ (at a density of $50 \mathrm{fish} / \mathrm{L}$ maximum) transportation times should be $24 \mathrm{~h}$, since oxygen levels in this experimental configuration reached values near the critical survival threshold.

As for electric conductivity, values exhibited significant increases across transportation times in all clove oil concentrations tested (Tab. II). According to Gomes et al. (2009), this increase is imputable mainly to the escalation of ammonia levels in the water. This pattern of increase in conductivity with transportation time has been observed during the carrying of the cardinal tetra, Paracheirodon axelrodi (Schultz, 1956) (Gomes et al. 2009).

In turn, $\mathrm{pH}$ and $\mathrm{CO}_{2}$ exhibited opposite behaviors, with $\mathrm{pH}$ falling during transportation, in all clove oil concentrations, whilst $\mathrm{CO}_{2}$ values were observed to increase (Tab. II). At the end of the transportation experiment, $\mathrm{pH}$ was significantly higher in the control group as compared to the fish anaesthetized with $18 \mathrm{mg} . \mathrm{L}^{-1}$ clove oil, while $\mathrm{CO}_{2}$ exhibited an opposite trend, with values significantly higher in the $18 \mathrm{mg} . \mathrm{L}^{-1}$ treatment group when evaluated against the control. This results was expected since was well established that increase in $\mathrm{CO}_{2}$ cause a decrease in pH. InOuE et al. (2005) also reported that $\mathrm{pH}$ decreased after $4 \mathrm{~h}$ of transportation of juvenile matrinxã (Brycon cephalus, Gunther) anaesthetized with $5 \mathrm{mg} . \mathrm{L}^{-1}$ clove oil, probably due to the increase in $\mathrm{CO}_{2}$ values.

Ammonia measurements in the control group did not diverge significantly across the different clove oil concentrations tested. In the treatments with the anaesthetic, ammonia concentration was markedly higher in the $24 \mathrm{~h}$ transportation period (Tab. II). The ammonia values at $24 \mathrm{~h}$ of transportation (10-11 mg. $\left.\mathrm{L}^{-1}\right)$ were below the lethal concentration threshold for Nile tilapia juveniles (Benli \& KüKSAL 2005). Tilapia juveniles tolerate high ammonia levels in the water (BENLI \& KÜKSAL 2005, Benli et al. 2008).

No mortality was observed in any of the clove oil anaesthesia concentrations in the $6 \mathrm{~h}$ transport measurement. Mortality of control fish and of the $9 \mathrm{mg} . \mathrm{L}^{-1}$ treatment group, after 12 and $24 \mathrm{~h}$ of transportation was only $0.67 \%$ (Tab. III). In the $18 \mathrm{mg} . \mathrm{L}^{-1}$ clove oil treatment, the mortality at $24 \mathrm{~h}$ of transportation $(3.67 \%)$ was significantly higher than the values observed for the other concentrations used. The Lake Victoria cichlid, Haplochromis obliquidens (Hilgendorf, 1888), anaesthetized with $18 \stackrel{1}{1 / 4} \mathrm{~L}^{\mathrm{L}} \mathrm{L}^{-1}$ of clove oil also revealed higher mortality rates after long transportation times ( $48 \mathrm{~h}$ ) (KAISER et al. 2006). Accumulated mortality, measured $96 \mathrm{~h}$ after transportation presented a similar tendency as compared to the mortality after the end of the transportation period, and was significantly higher in fish transported in $18 \mathrm{mg} . \mathrm{L}^{-1}$ clove oil for $24 \mathrm{~h}$. Total mortality for control fish and for fish anaesthetized with 9 mg.L $\mathrm{L}^{-1}$ clove oil was only $1.33 \%$.

DeRIGgi et al. (2006) reported that short-term exposures to eugenol did not affect the ion balance in Nile tilapia juveniles $(60 \mathrm{~g})$. However, in the treatments and transportation times tested in the present study, all fish presented $\mathrm{Na}^{+}$and $\mathrm{K}^{+}$ net eflux. 
Table III. Accumulated mortality ( $96 \mathrm{~h}$ after transportation), of $O$. niloticus juveniles for different times and at different clove oil concentrations. Data were analyzed by two-way ANOVA and Tukey test $(p<0.05)$. Lower case letters indicate statistical difference of the different treatments at one same transportation time. Upper case letters indicate statistical difference of different transportation times for one same treatment.

\begin{tabular}{|c|c|c|c|c|c|c|}
\hline \multirow{3}{*}{$\begin{array}{l}\text { Clove oil Concentration } \\
\left(\mathrm{mg} \cdot \mathrm{L}^{-1}\right)\end{array}$} & \multicolumn{3}{|c|}{ Mortality after transport (\%) } & \multicolumn{3}{|c|}{ Accumulated mortality 96 h (\%) } \\
\hline & \multicolumn{3}{|c|}{ Transportation time $(\mathrm{h})$} & \multicolumn{3}{|c|}{ Transportation time $(\mathrm{h})$} \\
\hline & 6 & 12 & 24 & 6 & 12 & 24 \\
\hline 0 & 0.00 aа & 0.67 aа & 0.67 aа & 0.67 аа & 1.00 aа & 1.33 aа \\
\hline 9 & 0.00 aа & 0.00 aа & 0.67 аа & 1.00 aа & $0.67^{\text {aa }}$ & 1.33 aa \\
\hline 18 & 0.00 aа & 0.00 aа & 3.67 bB & 0.33 aа & $0.33^{\text {aa }}$ & $5.67 \mathrm{bB}$ \\
\hline
\end{tabular}

$\mathrm{Na}^{+}$net eflux in fish transported in $18 \mathrm{mg} . \mathrm{L}^{-1}$ clove oil was significantly higher than in fish anaesthetized with all other concentrations, in the different transportation times $(6,12$, and $24 \mathrm{~h}$ ) (Fig. 1). The only exception was observed at the $24 \mathrm{~h}$ measurement, in which $\mathrm{Na}^{+}$net eflux in fish transported in $9 \mathrm{mg} . \mathrm{L}^{-}$ ${ }^{1}$ anaesthetic was similar as that in the fish transported in 18 $\mathrm{mg} . \mathrm{L}^{-1}$. In control fish and in the fish transported in $9 \mathrm{mg} . \mathrm{L}^{-1}$ clove oil, $\mathrm{Na}^{+}$net eflux was between two and three times as low as the value measured for fish transported in $18 \mathrm{mg} . \mathrm{L}^{-1}$ anaesthetic. The highest net flux values occurred in the $6 \mathrm{~h}$ transportation time, in all treatments; in the other transportation times a trend towards homeostasis was observed in fish. The fish also presented $\mathrm{K}^{+}$net flux in all treatments. The $\mathrm{K}^{+}$net flux pattern was similar to the one observed for $\mathrm{Na}^{+}$net flux. In the $6 \mathrm{~h}$ transportation measurement, the control group exhibited higher $\mathrm{K}^{+}$ net eflux, which in the subsequent measurements tended to be zero. Such trend has previously been observed for the pirarucu, Arapaima gigas (Schinz, 1822) (Gomes et al. 2006). The treatment with anaesthetic presented higher $\mathrm{K}^{+}$net eflux in the $6 \mathrm{~h}$ measurement, which was followed by a drop in the parameter in the $12 \mathrm{~h}$ measurement and a subsequent increase in the $24 \mathrm{~h}$ value (Fig. 2). Similar result was observed by Gomes et al. (2008) for the marbled hatchedfish, Carnagiella strigata (Günther, 1864), in which the animals revealed high $\mathrm{Na}^{+}$and $\mathrm{K}^{+}$net eflux, which decreased significantly after $24 \mathrm{~h}$ of transportation, reaching values near zero. The main reason to the observed $\mathrm{Na}^{+}$and $\mathrm{K}^{+}$ efflux in transported fish is an increase in gill permeability, which can cause a temporary hydromineral imbalance in the fish. In freshwater fishes, this can be manifested during acute stress as a loss in major blood ions (BARTON et al. 2002). This result suggests that $18 \mathrm{mg} . \mathrm{L}^{-1}$ clove oil induce additional stress in tilapia juvenile, as fish transported with this clove oil concentration presented a more evident ion efflux.

In conclusion, clove oil is an efficient anaesthetic for routine fish farming handling procedures for the Nile tilapia that require anaesthesia for up to $10 \mathrm{~min}$. The appropriate clove oil concentration to induce surgical anaesthesia is $90 \mathrm{mg} . \mathrm{L}^{-1}$, while for biometry procedures the best concentration of the anaesthetic is between 50 and $60 \mathrm{mg} . \mathrm{L}^{-1}$. As for transportation procedures, this anaesthetic should be avoided for Nile tilapia

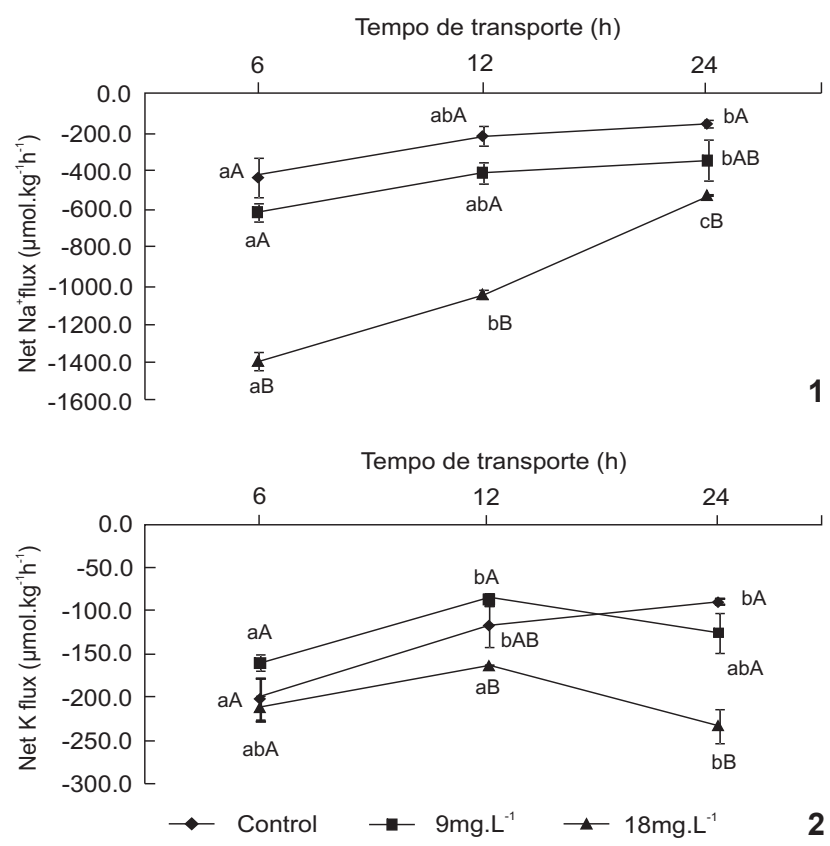

Figures 1-2. Net $\mathrm{Na}^{+}(1)$ and $\mathrm{K}^{+}$(2) flux during 6, 12 and $24 \mathrm{~h}$ of transportation of O. niloticus juveniles exposed to 0 (control), 9 and $18 \mathrm{mg} \cdot \mathrm{L}^{-1}$ of clove oil. Data were analyzed by two-way ANOVA and Tukey test $(p<0.05)$. Upper case letters indicate statistical difference of the different treatments at one same transportation time. Lower case letters indicate statistical difference of different transportation times for one same treatment.

juveniles, as this anaesthetic induce a greater osmorregulatory disturbance and mortality rate.

\section{ACKNOWLEDGEMENTS}

This paper was supported by an internal grant from UVV (\#9/2009). The authors are grateful to the biologist Adriana Virgens for the assistance in the ion analysis. L.C. Gomes is a research fellowship recipient from $\mathrm{CNPq} /$ Brasil. 


\section{LITERATURE CITED}

APHA. 1998. Standard Methods for the Examination of Water and Wastewater. New York, American Public Health Association, $18^{\text {th }}$ ed., 1050p.

Barton, B.A.; J.D. Morgan, \& M.M. ViJayan. 2002. Physiological and Condition-Related Indicators of Environmental Stress in Fish. In: ADAMS, S.M (Ed.). Biological Indicators of Aquatic Ecosystem Stress, p. 111-148. Bethesda, American Fisheries Society, 644p.

Benti, A.Ç.K. \& G. KöKSAL. 2005. The Acute Toxicity of Ammonia on Tilapia (Oreochromis niloticus L.) larvae and fingerlings. Turk Journal of Veterinary and Animal Sciences 29: 339-344.

Benli, A.Ç.K.; G. KöKsal \& A. ÖzKul. 2008. Sublethal ammonia exposure of Nile tilapia (Oreochromis niloticus L.): Effects on gill, liver and kidney histology. Chemosphere 72: 1355-1358.

Carneiro, P.C.F.; E.C URbinati \& M.L. Martins. 2002. Transport with different benzocaíne concentrations and its consequences on hematological parameters and gill parasite population of matrinxã Brycon cephalus (Gunther, 1869) (Osteichthyes, Characidae). Acta Science 24: 555-560.

Cooke, S.J.; C.D. Suski; K.G. Ostrand; B.L. Tufts, \& D.H. Wahl. 2004. Behavioral and physiological assessment of low concentrations of clove oil anaesthetic for handling and transporting largemouth bass (Micropterus salmoides). Aquaculture 239: 509-529.

Deriggi, G.F.; L.A.K.A. Inoue \& G. Moraes. 2006. Stress responses to handling in Nile tilapia (Oreochromis niloticus Linnaeus): assessment of eugenol as an alternative anaesthetic. Acta Scientiarum Biological Sciences 28: 269-274.

FAO. 2007. Fish Stats Plus: universal software for fishery statistical time series. Rome, v. 2.32.

Gonzalez, R.J.; C.M. Wood; R.W. Wilson; M.L. Patrick; H.L. Bergman; A. Narahara \& A.L. Val. 1998. Effects of water $\mathrm{pH}$ and calcium concentration on ion balance in fish of the Rio Negro, Amazon. Physiological Zoology 71: 15-22.

Gomes, L.C.; E.C. Chagas; R.P. Brinn; R. Roubach; C.E. Coppati \& B. Baldisserotto. 2006. Use of salt during transportation of air breathing pirarucu juveniles (Arapaima gigas) in plastic bags. Aquaculture 256: 521-528.

Gomes, L.C.; R.P. Brinn; J.L. Marcon; L.A. Dantas; F.R. Brandão; J.S. Abreu; D.M. Mссомв \& B. Baldisserotto. 2008. Using Efinol ${ }^{\circledR} L$ during transportation of marbled hatchetfish, Carnegiella strigata (Gunther). Aquaculture Research 39: 1292-1298.

Gomes, L.C.; R.P. Brinn; J.L. Marcon; L.A. Dantas; F.R. Brandão; J.S. Abreu; P.E.M. Lemos; D.M. Мсcomb \& B. Baldisserotto. 2009. The benefits of using probiotic Efinol ${ }^{\circ} \mathrm{L}$ during transportation of cardinal tetra, Paracheirodon axelrodi (Schultz) in Amazon. Aquaculture Research 40: 157-165.

Inoue, L.A.K.A.; L.O.B. Afonso; G.K. Iwama \& G. Moraes. 2005. Effects of clove oil on the stress response of matrinxã (Brycon cephalus) subjected to transport. Acta Amazonica 35: 289-295.

Iversen, M.; B. Finstad; R.S. Mckinley \& R.A. Eliassen. 2003. The efficacy of metomidate, clove oil, Aqui-S and Benzoak as anaesthetics in Atlantic salmon (Salmo salar L.) smolts, and their potential stress-reducing capacity. Aquaculture 221: 549566.

Kaiser, H.; G. Brill; J. Cahill; P. Collett; K. Czypionka; A. Green; K. Orr; P. Pattrick; R. Scheepers; T. Stonier; M.A. Whitehead \& R. YeARSLEy. 2006. Testing clove oil as an anaesthetic for longdistance transport of live fish: the case of the Lake Victoria cichlid Haplochromis obliquidens. Journal of Applied Ichthyology 22: 510-514.

Kiessling, A.; D. Johansson; I. H. Zahl \& O.B. Samuelsen. 2009. Pharmacokinetics, plasma cortisol and effectiveness of benzocaine, MS-222 and isoeugenol measured in individual dorsal aorta-cannulated Atlantic salmon (Salmo salar) following bath administration. Aquaculture 286: 301-308.

Mylonas, C.C.; G. Cardinaletti; I. Igelaki \& A. Polzonetti-Magni. 2005. Comparative efficacy of clove oil and 2-phenoxyethanol as anaesthetics in the aquaculture of European sea bass (Dicentrarchus labrax) and gilthead sea bream (Sparus aurata) at different temperatures. Aquaculture Research 246: 467-481.

Pálic, D.; D.M. Herolt; C.B. Andreasen; B.W. Menzel \& J.A. Roth. 2006. Anaesthetic efficacy of tricaine methanesulfonate, metomidate and eugenol: Effects on plasma cortisol concentration and neutrophil function in fathead minnows (Pimephales promelas Rafinesque, 1820). Aquaculture Research 254: 675-685.

Ross, G.L. \& B. Ross. 2008. Anaesthetic and Sedative Techniques for Aquatic Animals. Oxford, Blackwell Science, $3^{\text {rd }}$ ed., 222p.

Roubach, R.; L.C. Gomes; F.A.L. Fonseca \& A.L. Val. 2005. Eugenol as an efficacious anaesthetic for tambaqui, Colossoma macropomum (Cuvier). Aquaculture Research 36: 1-6.

Simões, L.N. \& L.C. Gomes. 2009. Eficácia do mentol como anestésico para juvenis de tilápia-do-nilo (Oreochromis niloticus). Arquivo Brasileiro de Medicina Veterinária e Zootecnia 61: 613-620.

Sтоsкорғ, M. 1993. Anaesthesia, p. 161-168. In: Brown L. (Ed.). Aquaculture for veterinarians: fish husbandry and medicine. London, Pergamon Veterinary Handbook Series, 462p.

Walsh, C.T. \& B.C. Pease. 2002. The use of clove oil as an anaesthetics for the longfinned ell, Anguilla reinhardtii (Steindachner). Aquaculture Research 33: 627-635.

WATERSTRAT, P.R. 1999. Induction and recovery from anaesthesia in channel catfish Ictalurus punctatus fingerlings exposed to clove oil. Journal of the World Aquaculture Society 30: 250255.

Zar, J.H. 1999. Biostatiscal Analysis. Upper Saddler River, Prentice Hall, $4^{\text {th }}$ ed., 663p.

Submitted: 05.VIII.2010; Accepted: 19.III.2011.

Editorial responsibility: Antonio Ostrensky Neto

ZOOLOGIA 28 (3): 285-290, June, 2011 